\title{
Periglandular inflammatory cells in the endometrium of the mare - A physiological defence mechanism which impacts on the development of endometrosis?
}

\author{
Kristin Klose and Heinz-Adolf Schoon \\ Institute of Pathology, Faculty of Veterinary Medicine, University of Leipzig, Germany
}

\begin{abstract}
Summary: During routine examination of equine endometrial biopsies periglandular accentuated mononuclear inflammatory cell infiltrates (PAMC) were often noted. The objective of this study was to characterise PAMC morphologically and immunohistologically with regard to their role in the mare's endometrium and their potential impact on the development of endometrosis. For this purpose, haemalaun and eosin (H\&E) stained sections of endometrial biopsies from 754 mares at the Institute of Pathology (Faculty of Veterinary Medicine, University of Leipzig) during 2009 were evaluated retrospectively for the presence of PAMC. They were diagnosed in 133 biopsies which were subsequently assessed in detail. Of these, 72 randomised samples were examined using special staining and immunohistochemical techniques to analyse the inflammatory cell populations involved in PAMC (CD3: T-lymphocytes; CD79A: B-lymphocytes; MAC387: macrophages; methyl green-pyronin staining: plasma cells), and characterise the affected gland epithelium and stromal cells by detecting intermediate filaments and microfilaments (vimentin, desmin, $\alpha$-smooth-muscle-actin) and assessing the integrity of the basal lamina of affected glands by detection of the basal lamina component laminin. PAMC occurred in about 18\% of all biopsy samples investigated during 2009 (133/754) and 96\% of these showed concurrent endometritis and/or endometrosis. The endometritis was composed of inflammatory cells similar to those observed in PAMC $(71 \%)$ or it contained varying numbers of neutrophils $(28 \%)$. Whereas mild-to-moderate endometrosis could be observed in the endometrium of $95 \%$ of the cases, the majority $(71 \%)$ of the endometrial glands surrounded by PAMC did not show any fibrotic alterations. In many PAMClocalisations (48\%) an infiltration of inflammatory cells into the glandular epithelium could also be seen. PAMC consisted mainly of T-lymphocytes and plasma cells. In addition, smaller numbers of B-lymphocytes and macrophages could also be detected. Within all PAMC foci, structural alterations were apparent in the basal lamina. Vimentin (60\%), desmin (17\%) and $\alpha$-smooth-muscle-actin $(\alpha$-SMA; $28 \%)$ were expressed by stromal cells surrounding the lesion. PAMC cannot be considered solely as a histopathological feature of lymphoplasmacell endometritis, but it is reasonable to interpret PAMC as a regular component of mucosa associated lymphoid tissue (MALT) in the equine endometrium. Furthermore the expression patterns of vimentin, desmin and $\alpha$-SMA in affected epithelial and stromal cells are comparable to findings in early stages of equine endometrosis as is the myofibroblast differentiation of perilesional stromal cells. PAMC were closely associated with alterations of the basal lamina of the endometrial glands involved. In general, the lesions involved in the basal lamina play a central role in the pathogenesis of equine endometrosis. Therefore, PAMC might be interpreted as one of the triggering factors for the development of endometrosis.
\end{abstract}

Keywords: endometrosis / endometritis / fertility disturbance / endometrial biopsy / reproduction / T-lymphocytes / basal lamina

Citation: Klose K., Schoon H.-A. (2016) Periglandular inflammatory cells in the endometrium of the mare - A physiological defence mechanism which impacts on the development of endometrosis?. Pferdeheilkunde 32,15-23

Correspondence: Dr. Kristin Klose, University of Leipzig, Faculty of Veterinary Medicine, Institute of Pathology, An den Tierkliniken 33, 04103 Leipzig, Germany. E Mail: kristin.klose@vetmed.uni-leipzig.de

\section{Introduction}

Several degenerative and inflammatory changes in the endometrium can cause infertility in mares. Over the past 20 years in the Institute of Pathology of the Faculty of Veterinary Medicine (University of Leipzig) some 16000 equine endometrial biopsies were examined for diagnostic purposes. Inflammatory and degenerative changes as well as maldifferentiation were the main lesions detected during these examinations (Ebert et al. 2014). Although the pathogenesis of endometritis, angiopathies and functional disturbances of the endometrium are nowadays well characterised, the aetiology of endometrosis remains unknown, although an inflammatory pathogenesis is suspected. During routine examinations of endometrial biopsies periglandular accentuated mononuclear inflammatory cells (PAMC) are detected regularly.

Although perivascular inflammatory cell infiltrations in the endometrium of the mare are well known to be associated with endometritis (Smith et al. 1993, Grüninger et al. 1998), the histopathological relevance of PAMC and their impact on the fertility of affected mares has not been clarified.
Aggregations of lymphocytes in the endometrium of normal, fertile mares is well described as part of the immune defence mechanisms (Frayne and Stokes 1994, Watson and Thomson 1996). In other studies the periglandular infiltrations are described as a symptom of endometritis (Kenney 1978, Watson and Thomson 1996). On the other hand periglandular accumulations of inflammatory cells are considered to be part of the normal physiological distribution pattern of inflammatory cells in the endometrium of women in some quarters (Morris et al. 1985, Marshall and Jones 1988, Disep et al. 2004) whereas they are found within endometritis and therefore considered to be pathological in others (Tawfik et al. 1996, Disep et al. 2004). In cattle, accumulations of inflammatory cells are also seen around glands affected by periglandular fibrosis occur as well (Cupps 1973, Espejel del Moral 2012).

Therefore the aim of the present study was to histomorphologically and immunohistologically characterise PAMC in the equine endometrium. In particular, to determine if PAMC are a physiological finding, an endometritis associated lesion or 
possibly a trigger for the initiation or the progression of periglandular fibrosis (equine endometrosis).

\section{Material and Methods}

During 2009 haemalaun and eosin (H\&E)-sections of all 754 of the equine endometrial biopsy samples submitted to the Institute of Veterinary Pathology were evaluated retrospectively for the presence of PAMC. These biopsies had been fixed in $4 \%$ neutral buffered formalin, embedded in paraplast using an automatic processor (Hypercenter XP; Shandon, Frankfurt, Germany), sectioned at 3-4 $\mu \mathrm{m}$ thickness and stained with H\&E. Biopsies which exhibited one or more foci of marked accumulation of inflammatory cells around endometrial glands that were not associated with similar infiltrates around arteries, veins or lymph vessels were selected $(n=133)$ for further study. Subsequently, the slides showing foci of periglandular infiltration were assessed in more detail by determining both the degree (see Table 1) and cell makeup of the periglandular lesion. The stage of the mare's oestrous cycle ('dating') (Kenney 1978, Kenney and Doig 1986, Brunckhorst et al. 1991, Schoon et al. 1992, Raila 2000) and the degrees and character of any concurrent endometritis (Kenney 1978, Schoon et al. 1997) (see Table 2) or

\begin{tabular}{ll}
\hline Table 1 & Classification of PAMC $\mid$ Graduierung der PAME \\
\hline Degree of severity & Number of inflammatory cell \\
\hline Mild & Focal $<5$ or multifocal $<3$ \\
Moderate & Focal $5-10$ or multifocal $3-5$ \\
Severe & Focal $>10$ or multifocal $>5$ \\
\hline
\end{tabular}

endometrosis (Kenney 1978, Hoffmann 2006) were also assessed and recorded.

Of these 133 biopsies, 72 were chosen randomly for further assessment by methyl green-pyronin staining (MGP) to detect plasma cells (Pallaske and Schmiedel 1959) and various other immunohistochemical techniques. The immunohistochemical markers applied to the sections and the cells or other structures examined are shown in Table 3. Immunohistochemistry was performed using the peroxidase anti-peroxidase (PAP) technique.

\section{Results}

Periglandular accumulations of mononuclear inflammatory cells (see Fig. 1) occurred in 133 of the 754 biopsies investigated routinely in 2009 (18\%). Over the course of the year, the percentage of samples exhibiting PAMC ranged from 10\% in October to 35\% in December. The proportion of biopsies with PAMC taken during winter anoestrus, i.e. January and December, was higher than during the physiological breeding season or the transitional periods between these two.

\section{Histomorphological characterisation}

PAMC lesions varied in degree of severity. A mild periglandular infiltration was seen in $57 \%$ of all the cases while a moderate cell infiltration was detected in $33 \%$. Only $10 \%$ of all the PAMC foci exhibited severe infiltrations. Around half of the PAMC foci (48\%) showed inflammatory cells infiltrating between the gland epithelial cells ('invasive'; see Fig. 2); this

\begin{tabular}{ll}
\hline Table 2 & Characterisation of endometritis \\
\hline Cellular character of endometritis & Involved inflammatory cells \\
\hline Suppurative & Dominance of neutrophile granulocytes, lymphocytes rare \\
Mixed-cellular & Neutrophilic granulocytes and lymphocytes/plasma cells in identical numbers \\
Lymphoplasma-cellular & Dominance of lymphocytes and plasma cells, neutrophilic granulocytes are very rare \\
Endometritis eosinophilica & Dominance of eosinophile granulocytes, frequently in combination with lymphocytes, plasma cells and \\
& scattered neutrophile granulocytes \\
\hline
\end{tabular}

Table 3 Immunohistochemical markers for the identification of inflammatory cells and cellular components | Angewandte immunhistologische Marker und durch sie nachweisbare Zellen und zelluläre Strukturelemente

\begin{tabular}{|c|c|c|c|}
\hline Immunohistochemical marker & Dilution & Source & Detectable cells/structures \\
\hline CD 3 (polyclonal antibody, rabbit anti-human) & $1: 300$ & A 04452 Dako GmbH, Hamburg & T-lymphocytes \\
\hline $\begin{array}{l}\text { CD 79A Clone HM57 (monoclonal antibody, } \\
\text { mouse anti-human) }\end{array}$ & $1: 15$ & M 7051 Dako GmbH, Hamburg & B-lymphocytes \\
\hline $\begin{array}{l}\text { Myeloid/histiocytic antigen Clone MAC } 387 \\
\text { (monoclonal antibody, mouse anti-human) }\end{array}$ & $1: 1000$ & M 0747 Dako GmbH, Hamburg & Macrophages \\
\hline Laminin (polyclonal antibody, rabbit anti-human) & $1: 100$ & $\begin{array}{l}\text { L-9393 Sigma Bioscience, St. Louis, } \\
\text { Missouri, USA }\end{array}$ & Basal lamina \\
\hline Vimentin (monoclonal antibody, mouse anti-pig) & $1: 200$ & M 0725 Dako GmbH, Hamburg & \\
\hline Desmin (monoclonal antibody, mouse anti-human) & $1: 200$ & M 0760 Dako GmbH, Hamburg & $\begin{array}{l}\text { Structural filaments in glandular } \\
\text { epithelial and stromal cells }\end{array}$ \\
\hline $\begin{array}{l}\alpha \text {-smooth muscle actin (mono-clonal antibody, } \\
\text { mouse anti-human) }\end{array}$ & $1: 100$ & M 0851 Dako GmbH, Hamburg & \\
\hline
\end{tabular}


was associated with disintegration of the epithelial cells leading up to complete destruction of the glands themselves. The remaining $52 \%$ of the PAMC foci were characterised as 'noninvasive' as the inflammatory cells around the glands had not infiltrated the gland epithelium.

The majority of the glands with associated inflammatory cell infiltrations (71\%) did not show any signs of periglandular fibrosis (endometrosis) as assessed by light microsopy. Only $22 \%$ of the PAMC are arranged around endometrotic glands; in $7 \%$ of the cases it was not possible to assess the presence or degree of endometrosis around PAMC affected glands due to the se--

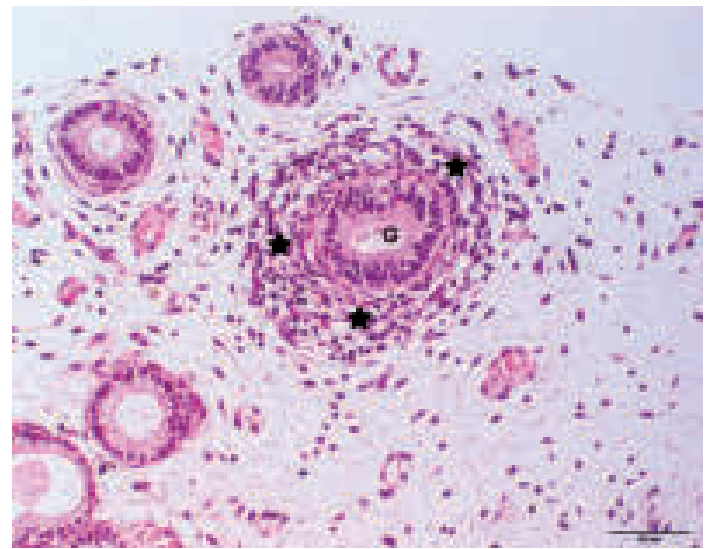

Fig. 1 Endometrial biopsy showing a cross section of an endometrial gland $(G)$ surrounded by mild periglandular accentuated mononuclear (lymphocytes and plasma cells) inflammatory cell infiltrations (PAMC) ( $\star$ ). No signs of endometritis in the remaining endometrium. Haemalaun and eosin. Bar $=50 \mu \mathrm{m}$.

Endometriumbioptat, endometriale Drüse im Querschnitt (G) mit einer geringgradigen periglandulär akzentuierten mononukleären (Lymphozyten und Plasmazellen) Entzündungszellinfiltration (PAME) ( ). Keine Endometritis im übrigen Endometrium. HaemalaunEosin-Färbung. Balken $=50 \mu \mathrm{m}$.

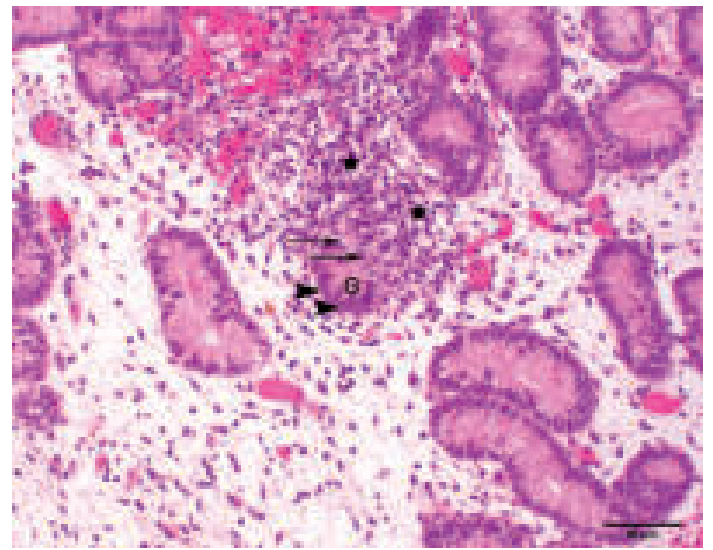

Fig. 2 Endometrial biopsy showing cross and longitudinal sections of endometrial glands. Endometrial gland $(G)$ surrounded by moderate PAMC ( $\star$ ), which is infiltrating ('invasive') the gland epithelium and is associated with moderate-to-severe segmental destruction (corresponding to the infiltrating PAMC) of the glandular epithelium (arrows). The epithelial structures outside the lesion show no alterations (arrowheads). Haemalaun and eosin. Bar $=50 \mu \mathrm{m}$.

Endometriumbioptat, Quer- und Längsschnitte endometrialer Drüsen. Endometriale Drüse (G), von mittelgradiger PAME (*) umgeben, Infiltration („invasiv") der periglandulären Entzündungszellen in das glanduläre Epithel, unter mittel- bis hochgradiger segmentaler Destruktion des betroffenen Epithels (Pfeile). Der extraläsionale Epithelbereich ist intakt (Pfeilspitzen). Haemalaun-Eosin-Färbung. Balken $=50 \mu \mathrm{m}$. verity of the periglandular inflammatory cell infiltration. Endometrosis is conveniently subdivided into active, inactive and mixed conditions (Hoffmann 2006). In 60\% of cases in the present study the activity of endometrosis around PAMC affected glands was identical to that in the remainder of the endometrium. However, in the remaining of the $40 \%$ of cases the degree of endometrosis around the PAMC associated glands was greater than in the remaining endometrium (see Fig. 3).

Some $89 \%$ of all biopsies with PAMC showed endometrosis in the residual endometrium. These included mild (48\%) to moderate $(47 \%)$ fibrotic alterations and only $5 \%$ of the samples exhibited severe endometrosis.

Endometritis was also a common finding and it was diagnosed in $63 \%$ of all the biopsies. Most of them showed a mild (67\%) or moderate $(30 \%)$ endometritis, and severe inflammation was seen in only $3 \%$. In $71 \%$ of cases the simultaneous endometritis could be characterised as lymphoplasmacellular and, hen$c e$, it composed of the same types of inflammatory cells observed in PAMC. However, in $29 \%$ of the cases, endometrial inflammation included varying numbers of neutrophils to give both suppurative and mixed-cell endometritis. An eosinophilic endometritis was observed in a single case. The percentage of biopsies showing moderate or severe endometritis increased with the severity of the PAMC (see Fig. 4, black lines). But independent of the severity of PAMC in each group there were examples which showed no inflammatory alterations.

\section{Immunohistochemical studies}

Immunhistochemical methods and methyl green-pyronine staining (MGP) were applied to characterise the inflammatory cell populations. In every PAMC-focus examined (100\%), Tlymphocytes were the dominant cell type. Furthermore in 30\% of the PAMC-foci small numbers of B-lymphocytes could be

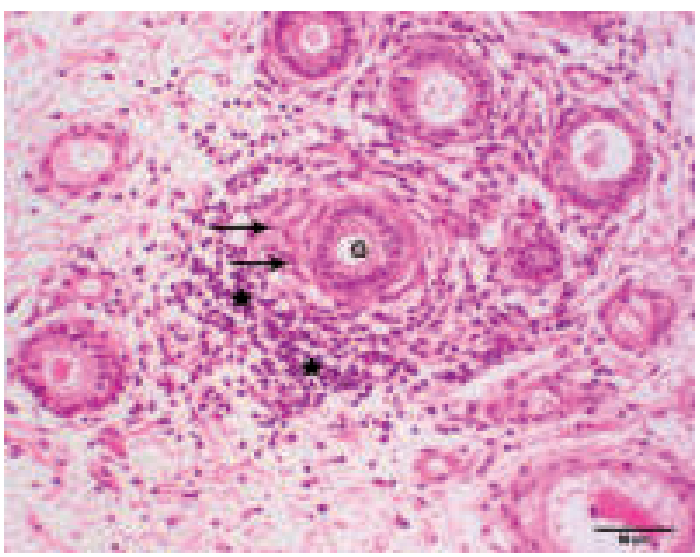

Fig. 3 Endometrial biopsy showing cross sections of endometrial glands. Endometrial gland $(G)$ surrounded by moderate PAMC ( $\star$ ), which is coincidently combined with an active, non-destructive endometrosis (periglandular fibrosis; arrows), characterised by randomly distributed, active (hypochromatic nuclei) periglandular stromal cells. Haemalaun and eosin. Bar $=50 \mu \mathrm{m}$.

Endometriumbioptat, endometriale Drüsen im Querschnitt. Endometriale Drüse (G), umgeben von mittelgradiger PAME ( ) bei gleichzeitigem Vorliegen einer aktiven, nicht-destruierenden Endometrose (periglanduläre Fibrose) (Pfeile), die durch eine ungeordnete Schichtung von aktiven (hypochromatische Zellkerne) periglandulären Stromazellen gekennzeichnet ist. Hämalaun-Eosin-Färbung. Balken $=50 \mu \mathrm{m}$. 


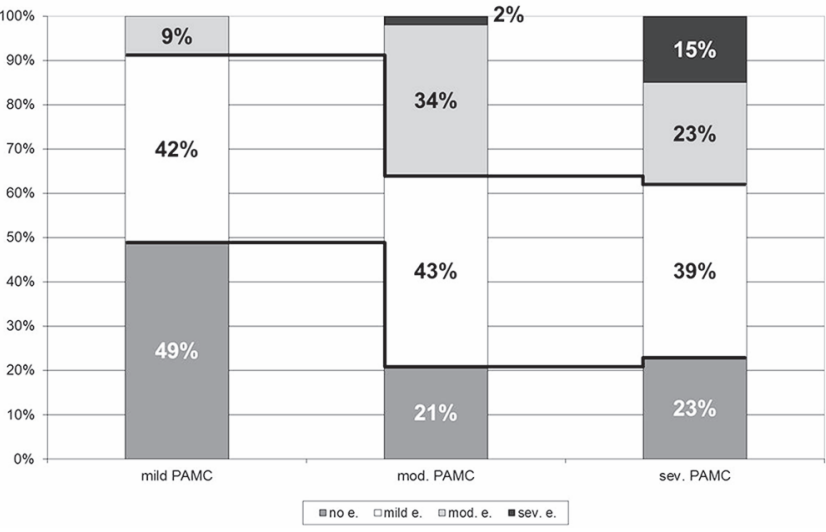

Fig. 4 Severity of endometritis (e.) parallel with the severity of PAMC. The percentage of samples with concurrent moderate or severe endometritis increase in parallel with moderate or severe PAMC (black lines).

Schweregrad der begleitenden Endometritis (e.) in Assoziation mit dem Ausprägungsgrad der PAME. Der Anteil an Bioptaten mit einer begleitenden mittelgradigen oder hochgradigen Endometritis nimmt bei Vorliegen einer mittel- oder hochgradigen PAME zu (schwarze Linien).

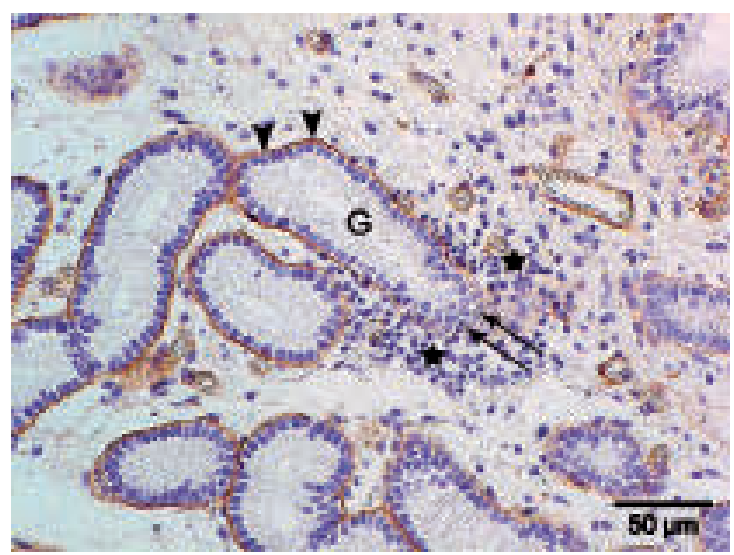

Fig. 5 Endometrial biopsy showing cross sections of endometrial glands. Immunohistochemical identification of the basal lamina component, laminin. An endometrial gland $(G)$ surrounded by mild PAMC ( $\star$ ) and showing discontinuous laminin expression (indicating destruction/alteration of the basal lamina) in areas affected by PAMC (arrows). Note the marked/distinctive and continuous expression of laminin (indicating continuous, intact basal lamina) in areas not affected by PAMC (arrowheads). Bar $=20 \mu \mathrm{m}$.

Endometriumbioptat, endometriale Drüsen im Querschnitt. Immunhistologischer Nachweis des Basallaminabestandteils Laminin. Endometriale Drüse $(G)$, umgeben von geringradiger PAME $(\star)$, undeutlicher Nachweis bis hin zum partiellen Verlust der Lamininexpression (hinweisend für eine Alteration/Destruktion der Basallamina) in den von der PAME betroffenen Arealen (Pfeile). In den nicht von einer PAME betroffenen Arealen wird eine deutliche und kontinuierliche Expression von Laminin (hinweisend für eine intakte, kontinuierlich verlaufende Basallamina) beobachtet (Pfeilspitzen). Balken $=20 \mu \mathrm{m}$. detected within the periglandular inflammatory cuffs. A few PAMC-foci (7\%) showed a moderate involvement of B-lymphocytes but in the majority of the PAMC-foci (63\%) no Blymphocytes could be observed. Macrophages were also found in small (17\%) and moderate (4\%) numbers in PAMCfoci while $79 \%$ of all PAMC comprised no macrophages at all. Plasma cells occurred in almost half the PAMC-foci: $37 \%$ of PAMC localisations showed a mild, and $9 \%$ a moderate, infiltration of plasma cells. All-in-all T lymphocytes and plasma cells were the most commonly occurring inflammatory cells (see Table 4).

Normal endometrial glands in a physiologically healthy endometrium are enclosed in an intact basal lamina, which is produced by the adjacent epithelial and stromal cells. The basal lamina represents the underlying foundation for the glandular epithelial cells and it is involved in their metabolism. Among others, the glycoprotein laminin is a major component of basal laminae (Timpl et al. 1979, Schittny u. Yurchenco 1989, Alberts et al. 2008) and in the present study the basal lamina was visualised by the immunohistochemical detection of laminin.

In all PAMC-localisations the basal lamina appeared to be discontinuous (see Fig. 5). These alterations varied from mild (24\%) to moderate (40\%) to severe (36\%). There was an association between the extent of the PAMC and the severity of the damage to the basal lamina. The proportion of PAMCfoci exhibiting severe basal lamina alterations increased with the degree of PAMC (see Fig. 6, black line).

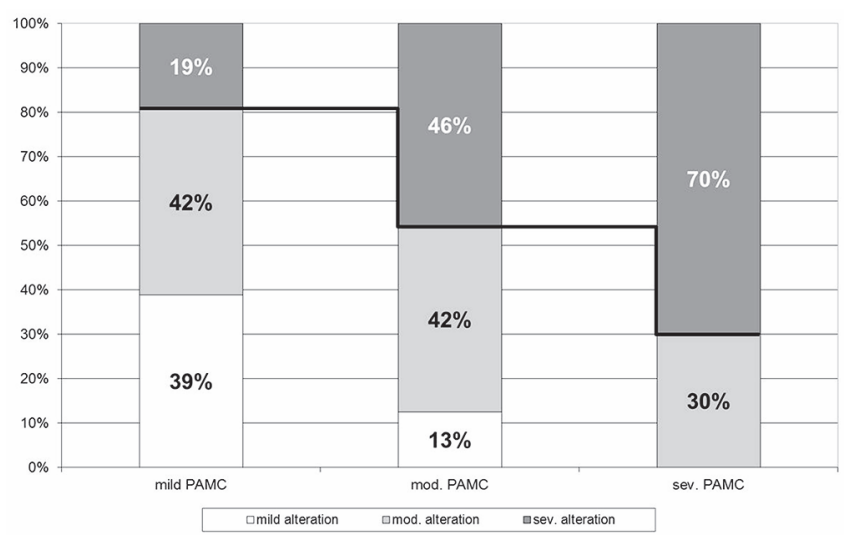

Fig. 6 Alteration of the basal lamina in association with varying degrees of PAMC. Severe alterations of the basal lamina are more often related to severe PAMC (black line).

Alteration der Basallamina in Assoziation mit unterschiedlichen Ausprägungsgraden der PAME. Hochgradige Alterationen der Basallamina stehen häufiger im Zusammenhang mit hochgradigen PAME (schwarze Linie).

Table 4 Inflammatory cell populations involved in PAMC | An der PAME beteiligte Entzündungszellpopulationen

\begin{tabular}{|c|c|c|c|c|}
\hline & \multicolumn{4}{|c|}{ Mononuclear inflammatory cells } \\
\hline & T-lymphocytes & B-lymphocytes & Macrophages & Plasma cells \\
\hline Occurrence in PAMC & +++ & + & + & ++ \\
\hline no & -- & $63 \%$ & $79 \%$ & $54 \%$ \\
\hline+ & -- & $30 \%$ & $17 \%$ & $37 \%$ \\
\hline++ & -- & $7 \%$ & $4 \%$ & $9 \%$ \\
\hline+++ & $100 \%$ & -- & -- & -- \\
\hline
\end{tabular}


Within only two of the PAMC-foci, epithelial cells within the lesion expressed vimentin while $59 \%$ of stromal cells within these PAMC-loci expressed vimentin (see Fig. 7). In parallel

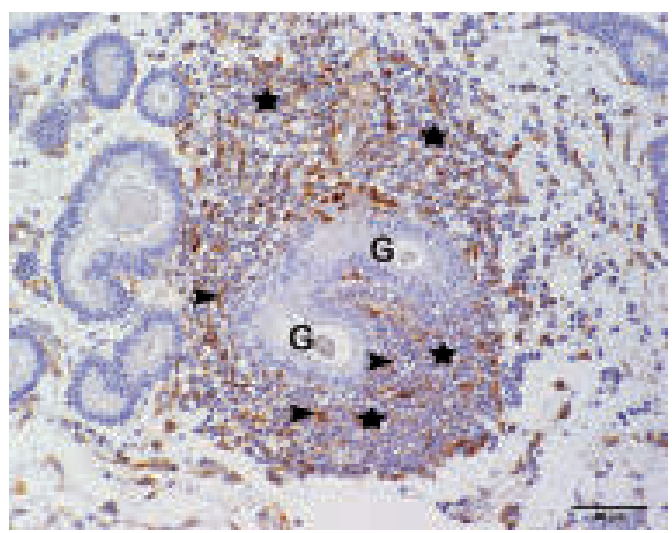

Fig. 7 Endometrial biopsy showing cross and longitudinal sections of endometrial glands. Immunohistochemical detection of the structural filament vimentin. An endometrial gland $(G)$ surrounded by severe PAMC $(\star)$.The stromal cells outside the gland (partly overlain by inflammatory cells) exhibit a multifocal moderate expression of Vimentin (arrowheads). A marked expression of vimentin in endometrial stromal cells is part of the typical immunhistochemical expression pattern of endometrial stromal cells in the early stages of endometrosis. Bar $=50 \mu \mathrm{m}$.

Endometriumbioptat, endometriale Drüsen im Quer- und Längsschnitt. Immunhistologischer Nachweis des Intermediärfilaments Vimentin. Endometriale Drüse (G), umgeben von hochgradiger PAME $\star$ *), in den periläsionalen Stromazellen (teilweise überlagert von Entzündungszellen) wird eine multifokale mittelgradige Expression von Vimentin beobachtet (Pfeilspitzen). Eine ausgeprägte Expression von Vimentin ist Teil eines für frühe Formen einer Endometrose typischen Expressionsmusters in endometrialen Stromazellen. Balken $=50 \mu \mathrm{m}$.

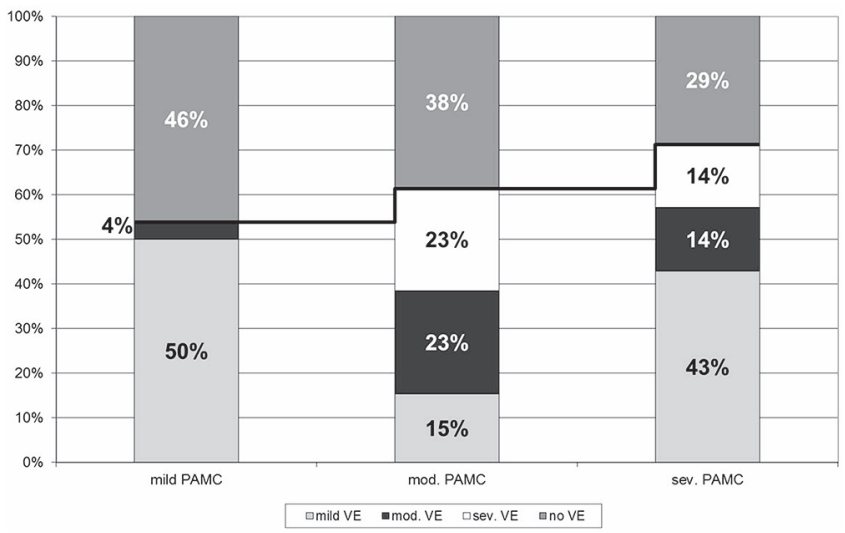

Fig. 8 Expression of vimentin (VE) in stromal cells outside the lesion in association with PAMC. The percentage of PAMC-foci with vimentin detectable in stromal cells outside the lesion increases with the degree of PAMC (black line).

Grad der Vimentin-Expression (VE) in den periläsionalen Stromazellen in Assoziation mit PAME. Der Anteil von PAME-Lokalisationen mit Nachweis einer Vimentin-Expression in den periläsionalen Stromazellen nimmt mit dem Schweregrad der PAME zu (schwarze Linie). with the increase in severity of PAMC the number of PAMCfoci with vimentin-expressing stromal cells also increased (see Fig. 8). The intermediate filament desmin and the microfilament $\alpha$-SMA were also detected in $17 \%$ and $28 \%$ of PAMClocalisations, respectively (see Figs. 9 and 10).

\section{Discussion}

In this study PAMC was detected in 18\% of 754 samples examined. In former studies involving equids (Kenney 1978, Frayne and Stokes 1994, Watson and Thomson 1996), bovids (Cupps 1973, Cobb and Watson 1995, Espejel del Moral 2012) and humans (Morris et al. 1985, Marshall and Jones 1988, Tawfik et al. 1996, Disep et al. 2004) periglandular cell infiltrations were also observed. The percentage of samples exhibiting PAMC varied from 5\% in human endometrium (Marschall and Jones 1988) to $33 \%$ and $36 \%$ respectively in the cow (Espejel des Moral 2012) and mare (Kilgenstein 2014). These differences are possibly due to diversity in the selection criteria used on the endometrial samples. In the present study no exclusion criteria were applied and all biopsies with PAMC examined during 2009 were included. However, these endometrial biopsies were frequently taken from

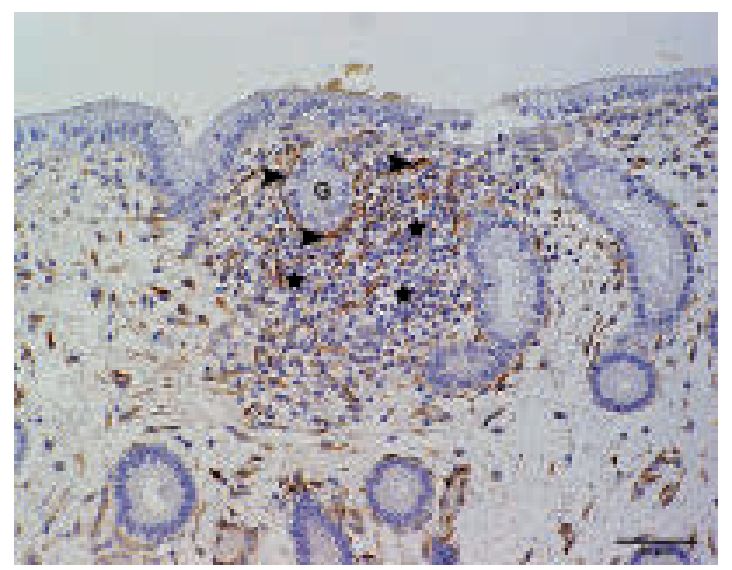

Fig. 9 Endometrial biopsy showing the luminal epithelium and cross and longitudinal sections of endometrial glands. Immunohistochemical detection of the structural filament, desmin. An endometrial gland $(G)$ surrounded by moderate PAMC ( $\star$ ). The stromal cells outside the gland (partly overlain by inflammatory cells) exhibit multifocal moderate expression of desmin (arrowheads). The expression of desmin in endometrial stromal cells is part of the typical immunhistochemical expression pattern of endometrial stromal cells in the early stages of endometrosis. Bar $=50 \mu \mathrm{m}$.

Endometriumbioptat, endometriale Drüsen im Quer- und Längsschnitt. Immunhistologischer Nachweis des Intermediärfilaments Desmin. Endometriale Drüse (G), umgeben von mittelgradiger PAME $\star \star$ ), in den periläsionalen Stromazellen (teilweise überlagert von Entzündungszellen) wird eine multifokale mittelgradige Expression von Desmin beobachtet (Pfeilspitzen). Eine Expression von Desmin ist Teil eines für frühe Formen einer Endometrose typischen Expressionsmusters in endometrialen Stromazellen. Balken $=50 \mu \mathrm{m}$.

Table 5 Endometrial expression of intermediate filaments and microfilaments in the mare / Expression von Intermediärfilamenten im equinen Endometrium

\begin{tabular}{|c|c|c|c|c|c|c|c|}
\hline & \multicolumn{2}{|c|}{ Vimentin } & \multicolumn{2}{|c|}{ Desmin } & \multicolumn{2}{|c|}{ Alpha-SMA } & \multirow{2}{*}{ PAMC } \\
\hline & Physiological & Endometrosis & Physiological & Endometrosis & Physiological & Endometrosis & \\
\hline EC & -- & pos. & -- & -- & -- & -- & pos. \\
\hline SC & pos. & pos. & .- & pos. & .- & pos. & pos. \\
\hline
\end{tabular}


mares with fertility problems. Nevertheless, considering the former and the present studies, and taking account of the different species involved, PAMC seems to be a frequent finding in the endometrium.

In the equine endometrium, PAMC occurs in varying degrees of severity and mild, moderate and severe periglandular cell infiltrations can be observed in the same or multiple localisa-

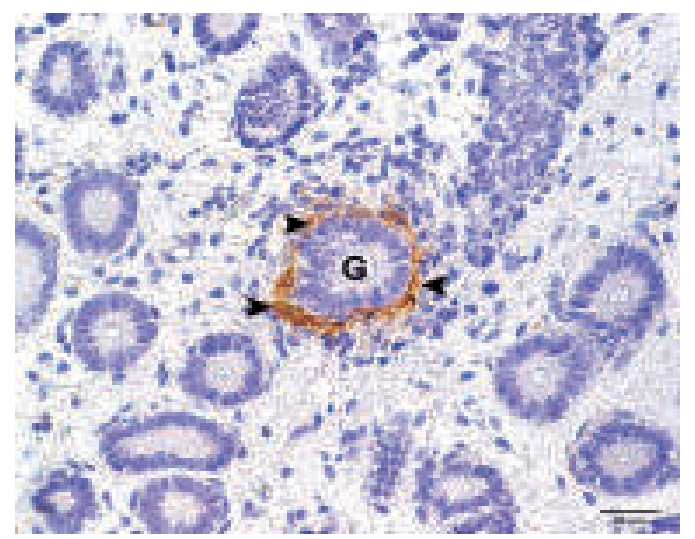

Fig. 10 a Endometrial biopsy showing cross sections of endometrial glands. Immunohistochemical detection of the microfilament $\alpha$-SMA. Endometrial gland $(G)$ surrounded by mild PAMC $(\star)$. In stromal cells outside the glands moderate circular expression of $\alpha$-SMA (arrowheads). The detection of $\alpha-S M A$ in endometrial stromal cells is symptomatic of differentiation to myofibroblast-like cells and is part of the typical immunhistochemical expression pattern of endometrial stromal cells in the early stages of endometrosis. Bar $=20 \mu \mathrm{m}$.

Endometriumbioptat, endometriale Drüsen im Querschnitt. Immunhistologischer Nachweis des Mikrofilaments $\alpha$-Aktin. Endometriale Drüse $(G)$, umgeben von geringgradiger PAME ( $)$, in den periläsionalen Stromazellen wird eine um die betroffene Drüse ringförmig angeordnete mittelgradige Expression von $\alpha$-Aktin beobachtet (Pfeilspitzen). Eine Expression von $\alpha$-Aktin in den endometrialen Stromazellen ist kennzeichnend für eine Differenzierung zu Myofibroblasten-ähnlichen Zellen und ist Teil eines für frühe Formen einer Endometrose typischen Expressionsmusters in endometrialen Stromazellen. Balken $=20 \mu \mathrm{m}$.

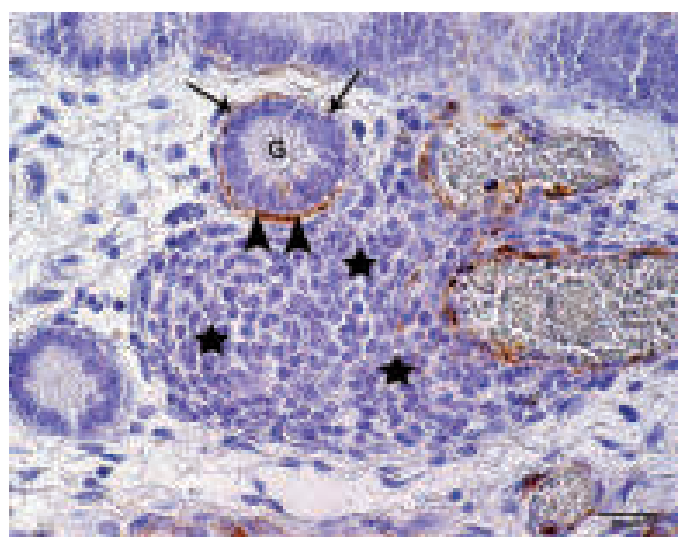

Fig. $10 \mathrm{~b}$ Endometrial biopsy showing cross sections of endometrial glands. Immunohistochemical detection of the microfilament $\alpha$-SMA. An endometrial gland $(G)$ surrounded by moderate PAMC $(\star)$. More intensive expression $\alpha$-SMA (arrowheads) is seen in stromal cells facing the PAMC compared to those outside the lesion (arrows). Bar $=50 \mu \mathrm{m}$.

Endometriumbioptat, endometriale Drüsen im Quer- und Längsschnitt. Immunhistologischer Nachweis des Mikrofilaments $\alpha$-Aktin. Endometriale Drüse (G), umgeben von mittelgradiger PAME ( ), intensivere Expression von $\alpha$-Aktin (Pfeilspitzen) in den Stromazellen des der PAME zugewandten Segmentes als außerhalb der PAME (Pfeile). Balken $=20 \mu \mathrm{m}$. tions. In women (Greenwood and Moran 1981, Tawfik et al. 1996), and in mares as revealed in the present study, a positive association exists between the occurrence of endometritis and PAMC. The latter consist predominantly of T-lymphocytes and plasma cells such that the periglandular infiltrates could be interpreted as a morphological appearance or residue of an endometritis caused by some persisting antigen stimulation. On the other hand, in the present study PAMC could also be detected in endometrial samples not exhibiting endometritis and, overall, the character of the endometritis does not match the lymphoplasmacellular character of the PAMC. Accordingly, an independent occurrence of PAMC has to be considered. In this regard, PAMC could be thought of as part of the mucosa- associated lymphoid tissue (MALT) in the uterus, comparable to other organ systems, such as the intestines or bronchi of the lungs. In studies of human endometrium it has been shown that periglandular inflammatory cell infiltrates meet the criteria of MALT (i.e. lymphoid aggregates and infiltration of T-lymphocytes into the epithelium) (Morris et al. 1985, Yeaman et al. 2001). These characteristics were also exhibited by the PAMC in the equine endometrium samples examined.

In the present study, the connection between periglandular inflammatory cells and endometrosis was investigated for the first time. Equine endometrosis is characterised by periglandular fibrosis and consecutive functional disturbances on fertility (Gordon and Sartin 1978, Doig et al. 1981, Heilkenbrinker et al. 1997, Schoon et al. 1997, Lehmann 2010).

In bovine endometrium, periglandular inflammatory cells occur in close relation to some extent endometrial glands affected by destructive glandular fibrosis. This was also found in the equine endometrium in the present study. Endometrosis of PAMC-glands can also be characterised as predominantly destructive, which offers two interpretations. 1) PAMC could be a consequence of the destruction of gland epithelium by endometrosis ('reactive') or, 2) (infiltrative) PAMC is the initial event that causes disintegration of gland epithelium and subsequently leads to periglandular fibrosis ('initial').

PAMC occurs in synchrony with alterations of the gland basal lamina. The damage to the basal lamina is possibly caused by the frequent infiltration of inflammatory cells (of PAMC) between the gland epithelial cells and the associated disintegration of these epithelial cells. The destructive process brought about by enzymes such as glycoproteinases or collagenases likely produced by the inflammatory cells involved (Tlymphocytes and macrophages) (Salamonsen 2003) as well as by affected stromal cells in the course of modification (Raila 2000). Additionally, the resulting fragments of the basal lamina attract inflammatory cells. The mechanism could contribute to the maintenance and self-generation of the periglandular inflammation.

Alterations of the basal lamina are known as the initial trigger within the pathogenesis of endometrosis (Raila 2000, Kiesow et al. 2011). An intact basal lamina is able to suppress the synthesis of profibrotic cytokines (Streuli et al. 1993), such as TGF $\beta$, whereas damage to the basal lamina causes activation of the reparative processes (Penney and Rosenkrans 1984) that, in the endometrium, takes the form of periglandular fibrosis i.e. equine endometrosis. 
In equine endometrosis a change is observed in the expression pattern of filaments within epithelial and stromal cells (Aupperle et al. 2004, Raila 2000, Walter et al. 2001, Hoffmann 2009, Böttcher 2011). While in the normal equine endometrium only the intermediate filament vimentin can be detected in stromal cells, in endometrosis vimentin is also found in epithelial cells. Furthermore the intermediate filament, desmin, and the microfilament, $\alpha$-smooth muscle actin ( $\alpha$-SMA), occur in stromal cells (Aupperle et al. 2004, Raila 2000, Hoffmann 2006) (see Table 5).

The present immunohistochemical investigations of epithelial and stromal cells involved in PAMC have revealed an expression pattern similar to that occurring in endometrosis (see also Table 5). Especially in equine endometrosis, the occurrence of cells, which, in ultrastructural and immunohistochemical features, are similar to myofibroblasts, has been reported by Evans et al. (1998) and Raila (2000). Myofibroblasts are a subpopulation of mesenchymal cells that, beside the expression of vimentin, show a co-expression of the contractile filaments desmin and/or $\alpha$-SMA (Sappino et al. 1988, Skalli et al. 1989, Masur et al. 1996, Mattey et al. 1997, Sandbo and Dulin 2011 ). In the present study, the stromal cells in areas of PAMC regularly showed co-expression of desmin $/ \alpha-S M A$. This suggests differentiation of the affected stromal cells to form myofibroblasts or myofibroblast-like cells, which is characteristic for stromal cells in equine endometrosis. Such cell transformation may be supported by cytokines (e.g. TGF- $\beta$ ) synthesised by the involved inflammatory cells (Branton and Kopp 1999, Atamas 2002), and involved mainly T lymphocytes (SchmittGraff et al. 1994, Zhang and Phan 1996, Olman 2009). Considering the PAMC-related alterations of the basal lamina and the fact that the immunhistochemical expression patterns of the stromal cells involved are comparable to those in endometrosis, a contribution of PAMC to the development of equine endometrosis appears possible. As seen in the present study, PAMC not only occurs in endometria afflicted with endometritis, but it also can be detected in non-inflammatory and healthy endometria, respectively. Thus, the endometrial biopsy can be once more a helpful tool to assess the development of or progression of endometrosis and, consequently, the fertility of the mare, since PAMC can be detected only by histopathological examination of a sample endometrium tissue.

\section{Acknowledgement}

The authors thank Ms Wipplinger and the histology laboratory of the Institute of Veterinary Pathology, University of Leipzig for excellent technical support.

\section{References}

Alberts B., Johnson A., Lewis J., RaffM., Roberts K., Walter P. (2008) Molecular Biology of the Cell. 5. Auflage, New York, Garland Science

Atamas S.P. (2002) Complex cytokine regulation of tissue fibrosis. Life Sci. 72, 631-643

Aupperle H., Schoon D., Schoon H.-A. (2004) Physiological and pathological expressione of intermediate filaments in the equine endometrium. Res. Vet. Sci. 76, 249-255

Böttcher D. (2011) Morphologisch-funktionelle Charakterisierung equiner endometrialer Epithel- und Stromazellen in Monokultur unter Einbeziehung immunzytologischer und transmissionselektronenmikroskopischer Methoden. Diss. Med. Vet. Leipzig
Branton M. H., Kopp J. B. (1999) TGF-beta and fibrosis. Microbes and Infection 1, 1349-1365

Brunckhorst D., Schoon H.-A., Bader H., Sieme H. (1991) Morphologische, enzym- und immunhistochemische Charakteristika des endometrialen Zyklus bei der Stute. Fertilität 7, 44-51

Cobb S. P., Watson E. D. (1995) Immunohistochemical Study of Immune Cells in the Bovine Endometrium at Different Stages of the Estrous-Cycle. Res. Vet. Sci. 59, 238-241

Cupps P. T. (1973) Uterine Changes Associated with Impaired Fertility in Dairy Cow. J. Dairy Sci. 56, 878-884

Disep B., Innes B. A., Cochrane H. R., Tijani S., Bulmer J. N. (2004) Immunohistochemical characterization of endometrial leucocytes in endometritis. Histopathology 45, 625-632

Doig P. A., McNight J. D., Miller R. B. (1981) The use of the endometrial biopsy in the infertile mare. Can. Vet. J. 22, 72-76

Ebert A., Schoon D., Schoon H.-A. (2014) Age related endometrial alterations in mares - biopsy findings of the last 20 years. Leipziger Blave Hefte: 7 Leipziger Tierärztekongress 2, 230-232.

Espejel del Moral M. (2012) Histomorphologische und immunhistologische Charakterisierung der Endometrose beim Rind. Diss. Med. Vet. Leipzig

Evans T. J., Miller M. A., Ganjam V. K., Niswender K. D., Ellersieck M. R., Krause W. J. (1998) Morphometric analysis of endometrial periglandular fibrosis in mares. Am. J. Vet. Res. 59, 1209-1214

Frayne J., Stokes C. R. (1994) MHC Class II positive cells and T cells in the equine endometrium throughout the oestrous cycle. Vet. Immunol. Immunopathol. 41, 55-72

Gordon L. R., Sartin E. M. (1978) Endometrial Biopsy As An Aid to Diagnosis and Prognosis in Equine Infertility. J. Equine Med. Surg. 2, 328-336

Greenwood S. M., Moran J. J. (1981) Chronic Endometritis - Morphologic and Clinical Observations. Obstet. Gynecol. 58, 176-184

Grüninger B., Schoon H.-A., Schoon D., Menger S., Klug E. (1998) Incidence and morphology of endometrial angiopathies in mares in relationship to age and parity. J. Comp. Pathol. 119, 293-309

Heilkenbrinker T., Kossin C., Scherbarth R., Frerking H. (1997) A field study to evaluate the efficacy of case historical and clinical parameters in increasing the precision of predicting the course of subsequent pregnancy. Dtsch. Tierärztl. Wschr. 104, 313-316

Hoffmann C., Bazer F. W., Klug J., Aupperle H., Ellenberger C., Schoon H.-A. (2009) Immunohistochemical and histochemical identification of proteins and carbohydrates in the equine endometrium: Expression patterns for mares suffering from endometrosis. Theriogenology 2, 264-274

Hoffmann C. (2006) Morphologisch-funktionelle Untersuchungen zur Pathogenese der equinen Endometrose unter besonderer Berücksichtigung endometrialer Proteine und Kohlenhydrate. Diss. Med. Vet. Leipzig

Kenney R. M. (1978) Cyclic and pathologic changes of the mare endometrium as detected by biopsy, with a note on early embryonic death. J. Am. Vet. Med. Assoc. 172, 241-62

Kenney R. M., Doig P. A. (1986) Equine Endometrial Biopsy, Current Therapy in Theriogenology, Morrow D.A., WB Saunders, Philadelphia, 2. Aufl., S. 723-729

Kiesow C, Ellenberger C, Schoon H.-A. (2011) Pathogenesis of equine endometrosis: Relevance of the growth factors transforming growth factor-alpha, -beta 1 , -beta 2 and -beta 3 and matrixmetalloproteinase-2. Pferdeheilkunde 27, 4-5

Kilgenstein H. J. (2014) Die Subfertilität der Sportstute: welchen Einblick gewährt die histopathologische Untersuchung von Endometriumbioptaten. Diss. med. Vet. Leipzig

Lehmann J. (2010) Morphologisch-funktionelle Untersuchungen zur prognostischen Bewertung der equinen Endometrose. Diss. Med. Vet. Leipzig

Marshall R. J., Jones D. B. (1988) An Immunohistochemical Study of Lymphoid-Tissue in Human-Endometrium. Int. J. Gynecol. Pathol. 7, 225-235

Masur S. K., Dewal H. S., Dinh T. T., Erenburg I., Petridou S. (1996) Myofibroblasts differentiate from fibroblasts when plated at low density. Proc Natl Acad Sci USA 93, 4219-4223

Mattey D. L., Dawes P. T., Nixon N. B., Slater H. (1997) Transforming growth factor beta 1 and interleukin 4 induced alpha smooth muscle actin expression and myofibroblast-like differentiation in human synovial fibroblasts in vitro: modulation by basic fibroblast growth factor. Ann. Rheum. Dis. 56, 426-431 
Morris H., Edwards J., Tiltman A., Emms M. (1985) Endometrial lymphoid tissue: an immunohistological study. J. Clin. Pathol. 38, 644-652

Olman M. A. (2009) Beyond TGF-beta: a prostaglandin promotes fibrosis. Nat. Med. 15, 1360-1361

Pallaske G, Schmiedel E. (1959) Pathologisch-histologische Technik. Parey Buchverlag, Berlin, Hamburg

Penney D. P., Rosenkrans W. A. (1984) Cell-Cell Matrix Interactions in Induced Lung Injury: the Effects of X-Irradiation on Basal Laminar Proteoglycans. Radiat. Res. 99, 410-419

Raila G. (2000) Zur Pathogenese der Endometrose der Stute - Morphologisch-funktionelle Untersuchungen. Diss. Med. Vet. Leipzig

Salamonsen L. A. (2003) Tissue injury and repair in the female human reproductive tract. Reproduction 125, 301-311

Sandbo N., Dulin N. (2011) Actin cytoskeleton in myofibroblast differentiation: ultrastructure defining form and driving function. Transl. Res. 158, 181-196

Sappino A. P., Skalli O., Jackson B., Schurch W., Gabbiani G. (1988) Smooth-muscle differentiation in stromal cells of malignant and non-malignant breast tissues. Int. J. Cancer 41, 707-712

Schittny J. C., Yurchenco P. D. (1989) Basement membranes: molecular organization and function in development and disease. Curr Opin Cell Biol 1, 983-988

Schmitt-Graff A., Desmouliere A., Gabbiani G. (1994) Heterogeneity of myofibroblast phenotypic features: an example of fibroblastic cell plasticity. Virchows Arch. 425, 3-24

Schoon H.-A., Schoon D., Klug E. (1992) Uterusbiopsien als Hilfsmittel für Diagnose und Prognose von Fertilitätsstörungen der Stute. Pferdeheilkunde 8, 355-362

Schoon H.-A., Schoon D., Klug E. (1997) Die Endometriumbiopsie bei der Stute im klinisch-gynäkologischen Kontext. Pferdeheilkunde 13, 453-464

Skalli O., Schurch W., Seemayer T., Lagace R., Montandon D., Pittet B. (1989) Myofibroblasts from diverse pathologic settings are heterogeneous in their content of actin isoforms and intermediate filament proteins. Lab. Invest. 60,275-285

Smith K. C., Whitwell K. E., Mumford J. A., Gower S. M., Hannant D., Tearle J. P. (1993) An Immunohistological Study of the Uterus of Mares Following Experimental-Infection by Equid Herpesvirus1. Equine Vet. J. 25, 36-40

Streuli C. H., Schmidhauser C., Kobrin M., Bissell M. J., Derynck R. (1993) Extracellular matrix regulates expression of the TGF-beta 1 gene. J. Cell Biol. 120, 253-260

Tawfik O., Venuti S., Brown S., Collins J. (1996) Immunohistochemical characterization of leukocytic subpopulations in chronic endometritis. Infect. Dis. Obstet. Gynecol. 4, 287-293

Timpl R., Rohde H., Robey P. G., Rennard S. I., Foidart J. M., Martin G. R. (1979) Laminin-a glycoprotein from basement membranes. J. Biol. Chem. 254, 9933-9937

Walter I., Handler J., Reifinger M., Aurich C. (2001) Association of endometrosis in horses with differentiation of periglandular myofibroblasts and changes of extracellular matrix proteins. Reproduction 121, 581-586

Watson E. D., Thomson S. R. (1996) Lymphocyte subsets in the endometrium of genitally normal mares and mares susceptible to endometritis. Equine Vet. J. 28, 106-110

Yeaman G. R., Collins J. E., Fanger M. W., Wira C. R. (2001) CD8(+) T cells in human uterine endometrial lymphoid aggregates: evidence for accumulation of cells by trafficking. Immunology $102,434-440$

Zhang K., Phan S. H. (1996) Cytokines and pulmonary fibrosis. Biol. Signals 5, 232-239

Erweiterte Zusammenfassung

\section{Periglanduläre Entzündungszellen im Endometrium der Pferdestute - physiologische Abwehrmechanismen mit Bedeutung für die Entwicklung der Endometrose?}

Als endometriale Ursachen für Fertilitätsstörungen treten, neben entzündlichen (Endometritis) und funktionellen (Fehldifferenzierung), auch degenerative Läsionen im Bereich des
Endometriums (Endometrose, Angiopathien) auf. Während sowohl die Endometritiden als auch die Fehldifferenzierungen ätiologisch und pathogenetisch gut charakterisiert sind, ist die Ursache der Endometrose weitgehend ungeklärt. Unter anderem wird eine entzündliche Genese diskutiert. Im Rahmen der histopathologische Routinediagnostik von Endometriumbioptaten der Stute zur Abklärung von Fertilitätsproblemen unbekannter Genese fielen regelmäßig periglanduläre mononukleäre Entzündungszellinfiltrate (PAME) auf. Die Bedeutung im histopathologischen und klinisch-gynäkologischen Kontext und damit ihre Relevanz für die Fertilität der betroffen Studie ist bisher nicht geklärt. Ziel der vorliegenden Studie war daher die histomorphologische und immunhistologische Charakterisierung der PAME im klinisch-gynäkologischen, jahreszeitlichen und endometrialen Kontext. Insbesondere sollte geklärt werden, ob das Phänomen der periglandulären Entzündungszellakkumulation Ausdruck eines physiologischen endometrialen Befundes bzw. ein Begleitsymptom einer Endometritis darstellt oder aber ein potentieller Einfluss der PAME auf die Entwicklung der Endometrose (Trigger) gegeben ist.

Zu diesem Zweck wurden alle im Jahr 2009 mittels einer Übersichtsfärbung (H.-E.-Färbung) im Institut für VeterinärPathologie der Universität Leipzig untersuchten Endometriumbioptate von Stuten $(n=754)$ hinsichtlich des Vorkommens einer PAME überprüft. Es konnten 133 Bioptate identifiziert werden, die ausführlich histopathologisch ausgewertet wurden. Von den 133 Bioptaten wurden 72 Bioptate zusätzlich anhand einer Methylgrün-Pyronin-Färbung (MGP) und immunhistologischer Verfahren beurteilt: Neben der Differenzierung der an der PAME beteiligten Zellpopulationen (T-Lymphozyten: CD3, B-Lymphozyten: CD79 A, Makrophagen: MAC 387, Plasmazellen: MGP), wurde das Vorkommen der Intermediärfilamente Vimentin und Desmin sowie von $\alpha$-Glattmuskel-Aktin ( $\alpha$-GMA) in den beteiligten Epithel- und Stromazellen untersucht. Die glanduläre Basallamina wurde mittels der Basallaminakomponente Laminin immunhistologisch dargestellt und charakterisiert. PAME kamen in 18\% aller im Jahr 2009 untersuchten Bioptate vor. Es handelt sich hauptsächlich um gering- und mittelgradig ausgeprägte Entzündungszellakkumulationen. In 48\% der PAME-Lokalisationen wurde eine Infiltration der periglandulären Entzündungszellen zwischen die Drüsenepithelzellen beobachtet. Dabei kann es zu einem Verlust der Integrität bis hin zu einer vollständigen Destruktion des Drüsenpithels kommen. 96\% der Bioptate weisen gleichzeitig eine Endometritis und/oder eine Endometrose auf. Während im übrigen Endometrium häufig (95\%) eine gering- bis mittelgradige Endometrose nachweisbar war, wiesen die PAME-Drüsen mehrheitlich (71\%) keine periglanduläre Fibrose auf. Die mit PAME-Drüsen assoziierte Endometrose kann überwiegend (67\%) als destruierend und zu 50\% als aktiv/gemischt charakterisiert werden. Ebenso häufig kann in den untersuchten Biopaten eine Endometritis festgestellt werden. Der Entzündungszellcharakter der begleitenden Endometritis stimmt in 29\% der Fälle nicht mit dem Entzündungszellbild der PAME (mononukleär, lymphoplasmazellulär) überein. Die PAME bestehen hauptsächlich aus T Lymphozyten (CD3-positiv). Daneben fanden sich, in geringerer und variierender Anzahl, Plasmazellen (MGP), B-Lymphozyten (CD79A-positiv) und Makrophagen (MAC387-positiv). Anhand der Expression der Basallaminakomponente Laminin wurden in allen untersuchten PAME-Lokalisationen Alterationen der Basallamina nachgewiesen. Die Läsionen der Basal- 
lamina waren bei mittel- und hochgradigen PAME graduell stärker ausgeprägt und stehen häufig (43\%) mit einer intraepithelialen Infiltration der Entzündungszellen im Zusammenhang. Vimentin wurde vereinzelt (4\%) in intraläsionalen Drüsenepithelzellen nachgewiesen. Periläsionale Stromazellen exprimieren zu 60\% Vimentin, zu 17\% Desmin und zu $28 \%$ $\alpha-G M A$.

Aufgrund des zum Teil unterschiedlichen Entzündungszellcharakters von PAME und begleitender Endometritis sowie des Vorkommens der PAME im nicht-entzündlich alterierten Endometrium, handelt es sich bei den periglandulären Entzündungszellinfiltraten wahrscheinlich nicht ausschließlich um ein "histopathologisches Symptom" einer chronischen nicht-eitrigen Endometritis. Vielmehr spricht dies dafür, dass, ähnlich wie im humanen Endometrium, die PAME einen physiologischen Bestandteil des Schleimhaut-assoziierten lymphatischen Gewebes (MALT) im equinen Endometrium darstellt, was in Folgeuntersuchungen der Klärung bedarf. Betrachtet man das immunhistologische Expressionsmuster der endometrialen Epithelund Stromazellen in Bereichen der PAME, sind diese mit dem Expressionsmuster bei Vorliegen einer Endometrose, besonders deren lichtmikroskopisch nicht erfassbaren Frühstadien, vergleichbar. In vorangegangenen Studien konnten ultrastrukturelle Veränderungen der Stromazellen bei einer beginnenden, zu diesem Zeitpunkt lediglich elektronenmikrospkopisch erfassbaren, periglandulären Fibrose nachgewiesen werden. Die ultrastrukturellen Veränderungen der Stromazellen resultieren in einer veränderten Expression von Intermdiär- bzw. Mikrofilamenten, die dem Expressionsmuster bei Vorliegen einer PAME entspricht. Des Weiteren wird auch eine, für die Endometrose typische, myofibroblastenähnliche Differenzierung der Stromazellen im Bereich der PAME nachgewiesen. PAME sind eng mit dem Vorliegen von Basallaminaalterationen verknüpft. Die Destruktion der Basallamina ist wahrscheinlich mit der Infiltration der periglandulären Entzündungszellen zwischen die Drüsenepithelzellen und/oder durch die Freisetzung proteolytischer Faktoren ausgehend von den Entzündungszellen zu erklären. Schäden der Basallamina resultieren in einer vermehrten reparationsbedingten periglandulären Zubildung von Bindegewebe. Dabei spielen möglicherweise die beteiligten Zellpopulationen, so z.B. T-Lymphozyten oder Fibroblasten, und die von ihnen produzierten profibrotischen Zytokine eine Rolle. Diese Prozesse könnten, unter Einbeziehung des Endometrose-typischen Expressionsverhaltens der intraläsionalen Epithel- und Stromazellen, als potentieller Ausgangspunkt für periglanduläre Fibrosen angesehen werden. Eine Beteiligung der PAME an der Pathogenese der equinen Endometrose ist daher als wahrscheinlich anzunehmen.

Wie die vorliegende Studie zeigt, treten PAME nicht nur im Zusammenhang mit einer Endometritis auf, sondern kommen auch im nicht-entzündlich alterierten bzw. gesunden equinen Endometrium vor. Da PAME nur im Rahmen der histopathologischen Untersuchung der Uterusschleimhaut nachweisbar sind, stellt die Beurteilung eines Endometriumbioptates der Stute auch in diesem Zusammenhang ein wichtiges diagnostisches Hilfsmittel dar, um eine mögliche Entwicklung oder die Progression einer Endometrose beurteilen zu können.

Schlüsselwörter: Endometrose / Endometritis / Fertilitätsstörung / Endometriumbiopsie / Reproduktion / T-Lymphozyten /

Basallamina 